\title{
PENGGUNAAN TEPUNG KULIT PISANG GOROHO (MUSA ACUMINAFE, L) DALAM RANSUM TERHADAP PERFORMANS AYAM RAS PETELUR
}

\author{
Anggraini Ruru, J. Laihad*, Jein Rinny Leke, Linda Tangkau.
}

Fakultas Peternakan Univrsitas Sam Ratulangi Manado. 95115

\begin{abstract}
ABSTRAK
Penelitian ini bertujuan untuk mengetahui sampai sejauh manapemberian Tepung Kulit Pisang Goroho (Mussa acuminafe, L) terhadap penampilan produksi ayam ras petelur. Ternak yang digunakan dalam penelitian ini adalah ayam ras petelur fase layer yaitu umur 36 minggu dari jenis MB 402 sebanyak 100 ekor. Perlakuan yang digunakan adalah Ransum Basal (R0), Ransum Basal 98\% + 2\% Tepung Kulit Pisang Goroho (R1), Ransum Basal 96\% + 4\% Tepung Kulit Pisang Goroho (R2), Ransum Basal 94\% + 6\% Tepung Kulit Pisang Goroho (R3), Ransum Basal 96\% + 8\% Tepung Kulit Pisang Goroho (R4). Variabel yang diamati meliputi Konsumsi ransum (g/ekor), Produksi telur (\%), Konversi ransum. Metode penelitian yang digunakan adalah metode percobaan menggunakan Rancangan Acak Lengkap dengan menggunakan 5 perlakuan dengan 5 ulangan dan tiap ulangan terdiri dari 4 ekor ayam petelur. Hasil Penelitian menunjukkan bahwa penggunaan tepung kulit pisang goroho dalam ransum ayam petelur tidak berpengaruh nyata $(\mathrm{P}>0.05)$ terhadap Konsumsi ransum, Produksi ransum dan Konversi. Berdasarkan hasil penelitian dapat disimpulkan bahwa penggunaan tepung kulit pisang goroho (Musa acuminafe, L) dalam ransum sebanyak $8 \%$ memberikan hasil yang sama terhadap konsumsi ransum, produksi telur, konversi ransum.
\end{abstract}

Kata Kunci: Penampilan produksi, Ayam petelur, Tepung Kulit Pisang Goroho.

\footnotetext{
*korespondensi (corresponding Author)

Email: Inelaihadh@gmail.co.id
}

\begin{abstract}
UTILIZATION OF GOROHO BANANA PEEL FLOUR (Musa acuminafe, L) IN RATION ON EGG PRODUCTION PERFORMANCE OF LAYING HENS. The objective of this study was to evaluate the utilization goroho banana peel flour (Musa acuminafe, $L$ ) in ration on production performance of laying hens (strain of MB 402). Total of 100 laying hens (strain of MB 402) at the age of 36 weeks old were used in this study. Treatments were using basal ration without goroho banana peel flour (R0), basal ration of $98 \%$ added with goroho banana peel flour of $2 \%$ (R1), basal ration of $96 \%$ added with goroho banana peel flour of $4 \%$ (R2), basal ration of $94 \%$ added with goroho banana peel flour of 6\% (R3), and basal ration of $92 \%$ added with goroho banana peel flour of $8 \%$ (R4). Each treatment was replicated in to 5 replications. Variables measured were including feed consumption (g/head/day), egg production (\%), and feed conversion. Completely randomized design was applied the research method with Duncan's multiple range test for the significance treatments affecting variables. Results showed that utilization goroho banana peel flour (Musa acuminafe, $L$ ) in ration did not significantly affect on feed consumption, egg production and feed conversion. Therefore, it can be concluded that utilization goroho banana peel flour (Musa acuminafe, $L$ ) in ration up to 8 percents might be applied in ration of laying hens (strain of MB 402).
\end{abstract}

Keywords: Egg production, performance, goroho banana peel flour, laying hens. 


\section{PENDAHULUAN}

Ayam ras petelur merupakan salah satu ternak unggas yang cukup potensial di Indonesia. Ayam ras petelur dibudidayakan khusus untuk menghasilkan telur secara komersial. Ayam ras petelur adalah betina dewasa yang menghasilkan telur dengan jumlah yang banyak. Produksi telurnya antara 250 sampai 280 butir per tahun. Telur pertama dihasilkan pada saat umur 5 bulan dan akan terus menghasilkan telur sampai umurnya mencapai 2 tahun (Silverdes, 2001).

Telur merupakan produk peternakan yang memberikan sumbangan besar bagi tercapainya kecukupan gizi masyarakat. Sebutir telur mempunyai gizi yang cukup sempurna karena mengandung zat-zat gizi yang lengkap dan mudah dicerna. Telur ayam secara fisik terdiri dari $10 \%$ kerabang (kulit telur, cangkang), 60\% putih telur dan 30\% kuning telur. Kandungan dari zat-zat makanan kuning telur yaitu protein 17,5\%, lemak 32,5\%. Ayam petelur kemudian dijadikan sebagai ayam unggulan dalam produksi telur. Dalam upaya peningkatan produksi telur, ternak unggas harus diberi pakan sesuai kebutuhan dan mengandung gizi sesuai rekomendasi. Produksi telur sangat erat kaitannya dengan konsumsi pakan, konversi ransum (Samli, 2006).
Pada pemeliharaan ayam ras petelur ransum merupakan biaya produksi yang terbesar yaitu 60-70\%, oleh karena itu diperlukan upaya mencari bahan pakan alternatif yang mudah didapat, dengan harga yang relatif murah tanpa mengabaikan nilai gizinya. Ransum yang baik bagi ayam petelur adalah ransum yang bisa memenuhi kebutuhan zat - zat makanan secara tepat sebab upaya peningkatan produksi telur, ternak unggas harus diberi ransum yang bergizi dan sesuai kebutuhan. Pemberian ransum yang baik tentunya akan berpengaruh terhadap produksi telur, konsumsi ransum, dan juga angka konversi pada ransum yang diberikan (Franz, 2010).

Pemanfaatan limbah sebagai bahan pakan ternak merupakan alternatif dalam meningkatkan ketersediaan bahan baku penyusun ransum. Limbah mempunyai proporsi pemanfaatan yang besar dari bagian-bagian tanaman atau hewan yang dijadikan sebagai protein kasar, sumber energi, sumber protein dan mineral. Bahan pakan kasar sebagian besar berasal dari sisa pengelolahan bahan pangan dan bijian, buah-buahan dan sayuran, limbah usaha peternakan dan pertanian. Limbah kulit pisang goroho adalah salah satu dari pengolahan bahan pangan.

Kandungan nutrisi kulit pisang goroho yaitu Berat Kering 91,56\%, Abu $5,39 \%$, Protein Kasar 6,74\%, Serat Kasar 
7,02\%, Lemak 0,67\%, Kalsium 0,97\%, Fosfor 0,40\%, dan Energi Metabolis 3828 $\mathrm{Kkal} / \mathrm{kg}$. Kulit pisang goroho memiliki potensi besar untuk dijadikan bahan ransum. Produksi limbah kulit buah pisang goroho pada tahun 2011 yaitu 89.159,7 ton (Dinas Pertanian Provinsi Sulawesi Utara 2011). Pengelolahan limbah kulit pisang goroho menjadi tepung adalah salah satu upaya untuk menanggulangi limbah kulit pisang (Asli, 2007).

\section{MATERI DAN METODE PENELITIAN}

Penelitian ini telah dilaksanakan melalui suatu percobaan selama 8 minggu bertempat di Perusahaan Peternakan Dharma Gunawan, yang terletak di Paniki Bawah, Kecamatan Mapanget Kota Manado, sejak tanggal 3 Juni - 29 Juli 2017 yang terdiri dari 7 hari masa pendahuluan dan 56 hari masa pengambilan data. Sedangkan ternak yang digunakan dalam penelitian ini adalah ayam ras petelur fase layer yaitu umur 36 minggu dari jenis MB 402 sebanyak 100 ekor yang secara acak dibagi 5 perlakuan dan 5 kali ulangan dan tiap ulangan diisi 4 ekor ayam. Bahan perlakuannya menggunakan ransum yang disusun berdasarkan kebutuhan ayam petelur dengan $17 \%$ protein dan energi metabolis $2700 \quad \mathrm{Kkal} / \mathrm{kg}$ dengan penambahan tepung kulit pisang goroho sebanyak $2 \%, 4 \%, 6 \%$, dan $8 \%$.

Metode Penelitian yang dilakukan tiap unit percobaan menggunakan 4 ekor ayam ras petelur, dengan bahan nransum sebagai berikut:

$\mathrm{RO}=$ Ransum basal $100 \%+0 \%$ Tepung kulit pisang goroho

$\mathrm{R} 1=$ Ransum basal $98 \%+2 \%$ tepung kulit pisang goroho

$\mathrm{R} 2=$ Ransum basal $96 \%+4 \%$ tepung kulit pisang goroho

R3 = Ransum basal 94\% $+6 \%$ tepung kulit pisang goroho

$\mathrm{R} 4=$ Ransum basal $92 \%+8 \%$ tepung kulit pisang goroho.

Rancangan Percobaan yang digunakan adalah Rancangan Acak Lengkap (RAL) dengan 5 perlakuan dan 5 ulangan. Model rancangan percobaan adalah:

$$
\mathrm{Yij}=\mu+\tau_{\mathrm{i}}+\sum \mathrm{ij}
$$

Yij = Variabel akan dianalisis pada ulangan ke-i ulangan ke-j

$\mu \quad=$ Rata-rata secara sebenarnya (nilai tengah populasi)

$\tau_{\mathrm{i}} \quad=$ Pengaruh perlakuan ke- $\mathrm{i}$

$\sum \mathrm{ij}=$ Galat eksperimen pada perlakuan ke-i ulangan ke-j

Variabel yang akan diamati yaitu:

1. Konsumsi ransum dihitung dengan cara menimbang sejumlah pakan yang diberikan (gram) dikurangi sejumlah 
Tabel 1. Kandungan Zat Makanan (\% Bahan Kering) Bahan Pakan Penelitian

\begin{tabular}{lrrrrrc}
\hline \multicolumn{1}{c}{ Bahan pakan } & Protein & Lemak & SK & Ca & P & $\begin{array}{c}\text { EM } \\
(\text { Kkal/kg) }\end{array}$ \\
\hline Jagung kuning $^{1}$ & 8,8 & 3,9 & 2 & 0,02 & 0,28 & 3350 \\
Dedak $^{1}$ & 12 & 13 & 12 & 0,12 & 0,5 & 1630 \\
Tepung Ikan $^{1}$ & 60 & 9 & 1 & 5,5 & 0,3 & 2830 \\
CaCO3 $^{2}$ & - & - & - & 0,29 & - & - \\
Konsentrat Cal 9.36 $^{2}$ & 29 & 10 & 7 & 3 & 2 & 2600 \\
Tepung Kulit Pisang $^{3}$ & 6,74 & 0,73 & 7,07 & 1,06 & 0,45 & 2925 \\
\hline
\end{tabular}

Ket: ${ }^{1}$ NRC 1994

${ }^{2}$ Sumber PT. Japfa

${ }^{3}$ Hasil analisa Laboratorium Fakultas Peternakan IPB Bogor

Tabel 2. Komposisi Ransum Percobaan

\begin{tabular}{lccccc}
\hline \multirow{2}{*}{ Komposisi pakan percobaan } & \multicolumn{5}{c}{ Jumlah \% } \\
\cline { 2 - 6 } & $\mathrm{R} 0$ & $\mathrm{R} 1$ & $\mathrm{R} 2$ & $\mathrm{R} 3$ & $\mathrm{R} 4$ \\
\hline Ransum kontrol & 100 & 98 & 96 & 94 & 92 \\
Tepung kulit pisang goroho & 0 & 2 & 4 & 6 & 8 \\
Total & 100 & 100 & 100 & 100 & 100 \\
\hline
\end{tabular}

Tabel 3. Komposisi Zat-Zat Makanan Ransum Percobaan

\begin{tabular}{lrrrrr}
\hline $\begin{array}{l}\text { Komposisi zat-zat } \\
\text { makanan }\end{array}$ & $\mathrm{R} 0$ & $\mathrm{R} 1$ & $\mathrm{R} 2$ & $\mathrm{R} 3$ & $\mathrm{R} 4$ \\
\hline Protein $(\%)$ & 17,75 & 17,54 & 17,32 & 17,10 & 16,87 \\
Serat Kasar (\%) & 4,37 & 4,42 & 4,48 & 4,53 & 4,58 \\
Lemak (\%) & 6,81 & 6,70 & 6,57 & 6,59 & 6,33 \\
$\mathrm{Ca}(\%)$ & 2,05 & 2,04 & 2,02 & 1,99 & 1,97 \\
$\mathrm{P}(\%)$ & 0,74 & 0,74 & 0,73 & 0,73 & 0,72 \\
EM (Kkal/kg) & 2811,70 & 2813,97 & 2816,23 & 2818,50 & 2820,77 \\
\hline
\end{tabular}

Keterangan: Hasil perhitungan berdasarkan Tabel 1 dan 2. 
pakan yang tersisa (gram) yang dilakukan setiap 24 jam sekali. Konsumsi pakan setiap minggu kemudian dijumlahkan untuk mengetahui konsumsi pakan total selama penelitian (Anggorodi, 1985).

2. Produksi telur harian (Hen day production). Presentase dari jumlah telur yang diproduksi oleh sejumlah ayam dalam kurun waktu tertentu (Dadang, 2006).

3. Konversi ransum dihitung setiap minggu dengan cara membandingkan jumlah pakan (g) yang dikonsumsi dengan massa telur (g/ekor/hari) setiap minggu (Dadang, 2006).

\section{HASIL DAN PEMBAHASAN}

Pengaruh penggunaan tepung kulit pisang goroho (Mussa Acuminafe) terhadap konsumsi ransum (g/ekor), produksi telur (\%) dan konversi pakan, dapat dilihat pada Tabel 4.

\section{Konsumsi Ransum}

Hasil analisa ragam (Tabel. 4) menunjukan pisang goroho pada ransum ayam ras petelur MB 402 tidak memberikan pengaruh nyata $(\mathrm{P}>0.05)$ terhadap konsumsi ransum. Dengan pengertian bahwa penggunaan tepung kulit pisang goroho dengan level 2\%, 4\%, 6\%, dan $8 \%$ dalam ransum ayam petelur $\mathrm{MB}$
402 secara statistik tidak menyebabkan perbedaan konsumsi ransum. Konsumsi ransum adalah banyaknya ransum yang dberikan dikurangi sisa ransum atau pakan yang menunjukkan rata-rata jumlah ransum yang dikonsumsi (Olgun, 2009). Penggunaan tepung kulit pisang goroho sampai level $8 \%$ dalam ransum ayam petelur tidak menyebabkan perbedaan konsumsi ransum. Konsumsi ransum yang berbeda tidak nyata antara lain disebabkan oleh kualitas terutama keseimbangan protein dan energi metabolis dalam ransum percobaan yang hampir sama (Kompiang, 2009). Faktor-faktor yang mempengaruhi konsumsi pakan yaitu status fisiologis dari ayam, tipe, strain, jenis kelamin, umur, berat badan, status gizi, lingkungan, palatabilitas, kualitas, bentuk dan ukuran pakan, kandungan energi dan protein. Selain itu pula konsumsi ransum tergantung pada komposisi pakan, temperature lingkungan, kepadatan pakan.

Penggunaan tepung kulit pisang memiliki kandungan protein yang rendah dan serat kasar yang tinggi. Banyak sedikitnya ransum yang dikonsumsi ternak tergantung juga pada kualitas bahan pakan yang dipergunakan untuk menyusun ransum, kesersian komposisi ransum, nilai nutrisinya sesuai dengan kebutuhan untuk pertumbuhan dan produksi yang optimal serta dipelihara dalam kondisi yang sama (Koni,2012). 
Tabel. 4. Data Rata-Rata Konsumsi Ransum, Produksi Telur, dan Konversi Ransum

\begin{tabular}{llll}
\hline & \multicolumn{3}{c}{ Variabel } \\
\cline { 2 - 4 } Perlakuan & $\begin{array}{l}\text { Konsumsi } \\
\text { Ransum(g/ekor) }\end{array}$ & Produksi Telur (\%) & Konversi Ransum \\
\hline R0 & $107,64 \pm 0,67$ & $90,36 \pm 3,42$ & $2,24 \pm 0,05$ \\
R1 & $110,16 \pm 0,91$ & $91,70 \pm 1,29$ & $2,23 \pm 0,07$ \\
R2 & $109,88 \pm 1,92$ & $92,24 \pm 2,73$ & $2,29 \pm 0,11$ \\
R3 & $109,61 \pm 1,09$ & $93,49 \pm 1,43$ & $2,19 \pm 0,02$ \\
R4 & $109,67 \pm 1,67$ & $94,01 \pm 1,42$ & $2,28 \pm 0,05$ \\
\hline
\end{tabular}

\section{Produksi Telur}

Hasil analisa ragam (Tabel. 4) menunjukan bahwa pemberian tepung kulit pisang goroho pada ayam ras petelur MB berpengaruh tidak nyata $(\mathrm{P}>0.05)$ terhadap produksi telur, karena adanya imbangan energi dan protein yang seimbang. Untuk mencapai kebutuhan ini ayam mampu mengatur konsumsi pakan sesuai dengan kandungan energi dan protein dalam pakan (Arvanitoyannis dan Kassaneti, 2008). Rataan berkisar 90,36 - 94,01\%. Walaupun secara statistik tidak nyata namun produksi telur menunjukan peningkatan dari perlakuan R1, R2, R3, dan R4.

Faktor utama yang mempengaruhi produksi telur adalah jumlah pakan yang dikonsumsi dan kandungan zat makanan. Jumlah pakan yang dikonsumsi berpengaruh terhadap jumlah telur yang dihasilkan. Produksi telur dipengaruhi oleh umur, fungsi fisiologis-anatomis ternak, pakan, penyakit, temperatur, dan kelembaban (Olgun, 2009).

\section{Konversi Ransum}

Konversi ransum dapat digunakan sebagai gambaran koefisien produksi, dimana semakin kecil nilai konversi semakin efisisen penggunaan ransum dan demikian sebaliknya. Hasil analisa (Tabel. 4) menunjukan bahwa pemberian tepung kulit pisang goroho pada ayam ras petelur tidak memberikan pengaruh yang nyata (P> 0.05) terhadap konversi ransum.

Konversi ransum dihitung setiap minngu dengan cara membandingkan jumlah pakan (g) yang dikonsumsi dengan massa telur (g/ekor/hari) setiap minggu. Berdasarkan data pada Tabel. 4 konversi ransum selama penelitian dari masing masing perlakuan diperoleh rataan konversi R0 (2,24), R1 (2,23), R2 (2,29) R3 $(2,19)$ dan R4 $(2,28)$. Konversi ransum merupakan salah satu ukuran yang banyak digunakan untuk menyatakan tingkat efisien pemanfaatan pakan oleh ternak yaitu perbandingan antara pakan yang dimakan dalam menghasilkan sejumlah telur (Fujiwara (2008). 
Kang (2003), menjelaskan konversi ransum erat kaitannya dengan konsumsi ransum dan produksi telur. Konversi pakan yang tinggi pada pakan lebih disebabkan karena konsumsi pakan yang rendah yang menyebabkan kecukupan asupan zat makanan ayam untuk memproduksi telur menjadi sedikit lebih rendah (Corillo, 2005).

\section{KESIMPULAN}

Penggunaan tepung kulit pisang goroho (Musa acuminafe, L) sampai level $8 \%$ dalam ransum memberikan hasil yang sama terhadap konsumsi ransum, produksi telur, dan konversi ransum.

\section{DAFTAR PUSTAKA}

Anggorodi. 1985. Ilmu Makanan Ternak Umum. Penerbit Gramedia. Jakarta.

Arvanitoyannis, I. dan A. Kassaveti. 2008. Fish Industri Waste: Treatments, environmental impact, current and potential uses. International Journal of food Science and technology. Vol 43(4): $726-745$.

Asli, M.M., S. A. Hosseini, H. Lorfollahian, dan F. Shariatmadari. 2007. Effect of Probiotic, Yeat, Vitamin E and Vitamin C supplements on performance and immune response of laying hen during high environment temperature. International Journal of Poultry Science. 6 (12): 895-900.

Corillo-Dominingues, S., M.E. Carranco Jauregui, R.M. Catillo-Domingues,
M.I. Castro-Gonzales, E. AvilaGonzales, F. Perez-Gil. 2005. Cholestrol and n-3 and n-6 fatty acid content in eggs from laying hens fed with red crab meal (Pleuroncodes planipes). Journal. Poult Sci 84:167172.

Dadang, R. A. 2006. Effect Of Rice Bran and Phytase Supplementation on Egg Laying Performance and Egg Quality of Laying Hens. Thesis. University Malaysia.

Franz, C., K. H. C. Baser and W. Windisch. 2010. Essential oils and aromatic plants in animal feeding - a European perspective. A review. Flavour Fragr. Journal. 25: 327-340.

Fujiwara. K., Y. Miyaguchi. A. Toyoda, Y. Nakamura, M. Yamazaki., K. Nakashima and H. Abe. 2008. Effect of fermented soybean "Natto" supplement on egg production and qualities. Asian-Aust. Journal Anim. 21 (11): 1610-1615.

Kang, D. K., S. I. Kim, C. H Cho, Y. H, Yim \& H. S. Kim. 2003. Use of lycopene, an antioxidant caratenoid, in laying hens for egg yolk pigmentation. Asian- Aust. Journal. Anim. Sci. 16 (12):1799-1803.

Kompiang, I.P. 2009. Pemanfaatan mikroorganisme sebagai probiotik untuk meningkatkan produksi ternak unggas di Indonesia. Jurnal Pegembangan Inovasi Pertanian 2 (3): 117-191.

Koni, T. 2012. Pemanfaatan kulit pisang dan ampas kelapa sebagai pengganti jagung dalam ransum terhadap pertumbuhan ayam buras. Buletin Partener 19:197-203. 
National Research Council. 1994. Nutrient Requirements of Poultry. Eighth Revised Edition. National Academy of Sciences. Washington.DC.

Olgun, O., Y. Cudafar and A.O Yildiz 2009. Effect of Boron Supplementation Feed with Low Calcium to Die Performance and Egg Quality in Method Laying Hens, Journal. Anim. Vet adv. S (4) 650654.

Samli H. 2006. Using brain in layer diets. Journal. Cent. Eur. Agric. 7 (1): 135.

Silverdes, F.G., T.A. Scott. 2011. Effect of storage and layer age on quality of eggs from two lines of hens. Journal Poultry Sci.80:1240- 1245.

Steel, R.G.D. dan J.H. Torrie. 1995. Principles and Procedures of Sattistics. Mc Graw-Hill.Inc. New York. 